\title{
Latrubesse Special Issue
}

\section{Relationship between vegetation of the levee neo-ecosystems and environmental heterogeneity in the Lower Delta of the Paraná River, Argentina}

\author{
Fabio Kalesnik ${ }^{1}$, Pablo Aceñolaza ${ }^{2}$, Martín Hurtado ${ }^{3}$ \& Jorge Martínez ${ }^{3}$ \\ ${ }^{1}$ Grupo de Investigación en Ecología de Humedales, Dpto. Ecología, Genética y Evolución, Universidad de Buenos Aires, Buenos Aires, Argentina; \\ ${ }^{2}$ CONICET, Centro de Investigaciones Científicas y de Transferencia de Tecnología a la Producción (CICyTTP), Diamante, Entre Ríos, Argentina; and \\ ${ }^{3}$ Instituto de Geomorfología y Suelos, Facultad de Ciencias Naturales y Museo, Universidad Nacional de La Plata, La Plata, Buenos Aires, Argentina
}

\author{
Keywords \\ alien plant species; Lower Delta; native tree \\ species; neo-ecosystems; secondary forest; \\ wetlands.

\section{Correspondence \\ Fabio Kalesnik, Grupo de Investigación en Ecología de Humedales, Dpto. Ecología, Genética y Evolución, Universidad de Buenos Aires, Buenos Aires, Argentina. Email: fabiokales@yahoo.com.ar}

doi:10.1111/j.1747-6593.2009.00196.x

\begin{abstract}
The relationship between environmental heterogeneity and the vegetation of the levee neo-ecosystems in the Delta of the Paraná River was studied. These habitat types were considered plant communities of recent origin related to local productive activities. Vegetation coverage was evaluated in 97 plots of three different environmental units (A, B and C), using classification analysis, indirect and direct ordinations. The differential vegetation in different environmental units could be related to a greater fluvial influence of the Paraná River on unit A and a greater tidal influence of the de la Plata River on units B and C. The Lower Delta hydrological regimes only affect a few of edaphic variables particularly $\mathrm{pH}$, organic matter percentage and clay content. To understand the spatial pattern of neo-ecosystems vegetation, it is also necessary to consider the invasion of alien species that has been taking place for over 50 years.
\end{abstract}

\section{Introduction}

The hydrological regime is the main factor conditioning wetland habitats, determining the salient characteristics of the communities present (Gosselink \& Turner 1978; Lugo et al. 1990; Mitsch \& Gosselink 2000).

The local hydrological regimes in each sector of the Lower Delta of the Paraná River are determined by marked differences in the landscape morphology, resulting in a high environmental heterogeneity (Kandus \& Adámoli 1993).

These two factors condition the response of the different plant communities (marshlands, Ceibo forests, Junco marshes and others) found in the area (Kandus 1997).

Few works have analysed the relationship between the environmental heterogeneity of the Lower Delta and the plant communities in relation to the productive areas (Valli 1990; Kalesnik 2001; Kalesnik \& Malvárez 2003).

A relationship has been shown between landscape patterns, local hydrological regimes and marsh recovery after afforestation abandonment in the lower ground of the islands (Valli 1990).

In the present work, we examined the existence of a relationship between the heterogeneity of the region and the characteristics of wetlands in higher ground (levees). Until the late XIX century, these were occupied by 'Monte Blanco', a very diverse and complex gallery forest formed of species endemic to the Upper Paraná Atlantic Forest and Chaco's woodlands (Burkart 1957; Menalled \& Adámoli 1995). Later on, human settlements focused mainly on these areas and the 'Monte Blanco' was almost entirely displaced, with only a few small relics remaining today (Kalesnik 2001; Vallés et al. 2005). Therefore, today, levees sustain vegetation that is completely different from that of their origin, defining several types of 'neo-ecosystems'. This term was first introduced by Morello et al. (2000) to characterize anthropized, seminatural areas in which the dominant or more abundant plant species are alien invaders, while the accompanying species are native.

These neo-ecosystems appear in the Lower Delta as afforestations of willow (Salix spp.) and poplar (Populus spp.) with various degrees of management, ranging from young active afforestations to afforestations with over 50 years of abandonment, which give way to new secondary forests dominated by alien tree species (Kalesnik 2001; Vallés 2004).

We hypothesize that the composition of levees' neoecosystems differs according to the landscape patterns 
and the hydrological regimes that characterize the various ecological units of the Lower Delta. To test this hypothesis, the plant communities in different types of neoecosystems were identified and characterized; then, the relationship between the regional environmental heterogeneity and the salient characteristics of the aforementioned plant communities was analysed; and finally, the edaphic parameters were examined to determine whether they had a differential response depending on the environmental units and types of neo-ecosystems.

\section{Methods}

\section{Study site: 'Bonaerense Lower Delta'}

This study was conducted in the Lower Delta of the Paraná River located in Buenos Aires Province (Fig. 1), covering an area of $2071.06 \mathrm{~km}^{2}$ (Latinoconsult 1972). The climate is temperate-subhumid with mean annual temperatures around $17^{\circ} \mathrm{C}$ and annual precipitations of $1073 \mathrm{~mm}$ (Servicio Meteorológico Nacional 1980). The Lower Delta islands are located on the terminal portion of the Paraná River Delta, at the point of its bifurcation into two main branches: Paraná Guazú and Paraná de las Palmas. The Paraná River and the De la Plata River's Estuary mainly influence the area's hydrological regime (Mujica 1979). The first has a seasonal cycle with a high flow starting in September that may cause occasional floods such as the ones that took place in 1905, 1966 and 1982-1983 [Dirección Nacional de Construcciones Portuarias y Vías Navegables Anuario Hidrográfico (1976-1980) (DNCP) 1983; Bonetto 1986]. The Uruguay River has minimal influence on the area.

The Bonaerense Lower Delta islands are formed by the accretion of silts transported and deposited by the Paraná River in the De la Plata River. They are plate-shaped and surrounded by a perimetric levee ( $20 \%$ of the total area) that encloses a depressed centre $(80 \%$ of the area) (Bonfils 1962). Marshlands cover the inner portion, being the only natural ecosystem present (Kandus \& Adámoli 1993). In levees, the original forest gallery was replaced almost entirely by afforestations of Salicaceas, with only small patches remaining today (Kalesnik 2001; Vallés et al. 2005).

Among the hydromorphic soil types found in the levees, humic, subhumic gley and alluvial soils were the most common (Bonfils 1962). According to the US Soil Taxonomy (Soil Survey Staff 2003); they correspond to Mollisols and Entisols (Endoaquolls, Hapludolls and Endoaquents) (Godagnone et al. 2002).

The spatial distribution of habitats and hydrological dynamics are the main factors defining four distinct ecological units in the Lower Delta area, as proposed by Kandus (1997) (Fig. 1).

Unit A consists of a deltaic plain (Summerfield 1991) with a strong fluvial influence due to the seasonal rise of the Paraná River.

The annual flood frequency is rather low but the area can remain flooded for over 6 months at the time of the highest seasonal flow. Extraordinary floods due to the 'El Niño' also have a strong impact on this unit. It is comprised of large islands, with most of their extension consisting of permanently inundated lowlands surrounded by perimetral levees.

Unit B, located downstream from A and referred locally to as the 'afforestation core area', has a transitional hydrology between the fluvial influence of the Paraná River and the tidal influence of the De la Plata River. The islands in this unit show a high degree of anthropic alteration.

Unit $\mathrm{C}$ forms the front of the delta and is subjected to the direct influence of the tidal and eolic tides of the De la

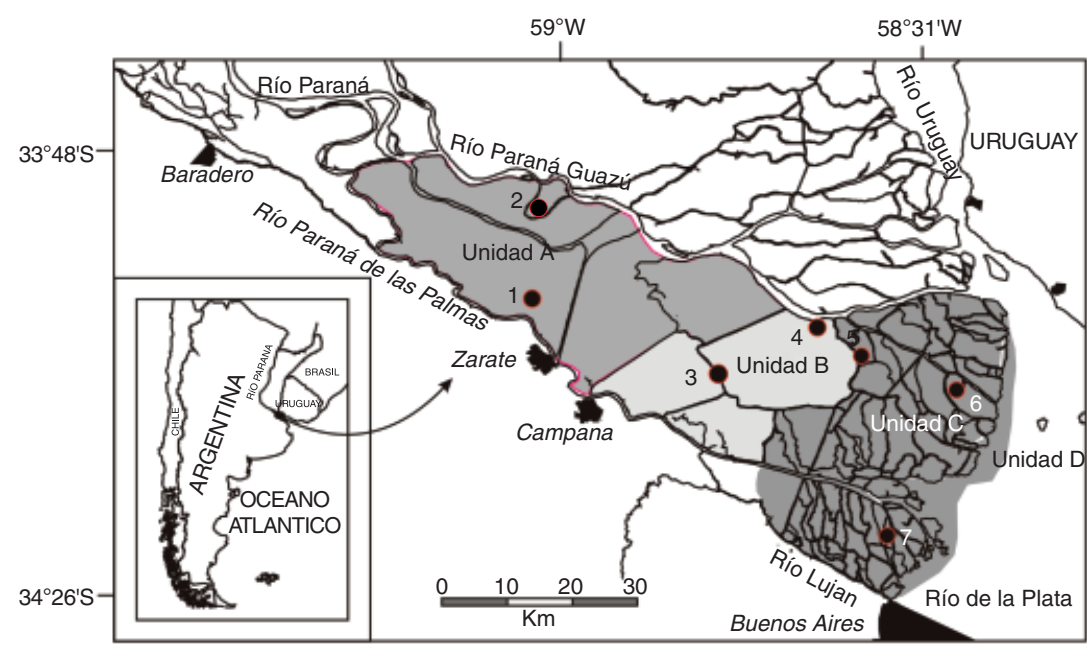

Fig. 1. The Lower Delta of the Parana River. Sampling sites: 1, Paraná de las Palmas. Arroyo ñacurutú. 2, Isla Botija; 3, Río Carabelas; 4, Paraná Guazú; 5, Paraná Miní; 6, Río Barca Grande; 7, Arroyo Boraso. Ecological units: A, B, $\mathrm{C}$ and $\mathrm{D}$ (see 'Methods'). 
Plata River, which range from 1 to over $3 \mathrm{~m}$ during strong south-eastern winds. From the Paraná Guazu and Paraná de las Palmas Rivers, numerous streams fan out, bordering small plate-shaped islands with a perimetral levee and a depressed centre dominated by Cortadera marshes (Scirpus giganteus). Salicaceas afforestations in this area, performed by an open ditch technique, have completely replaced the original vegetation of the levees (Monte Blanco).

The delta's progradation portion, where it grows by the deposition of sediments carried on the main rivers on their way to their mouth in the De la Plata River forming new islands and banks, constitutes unit $\mathrm{D}$.

These islands have scantily developed levees and are continued downstream by extensive sediment banks that are only exposed during the lowest flow periods of the De la Plata River. This unit was not evaluated in the present work because the levees' habitats are not developed enough.

In summary, the hydrological regime of the Lower Delta is subjected to a mainly fluvial-tidal north-eastsouth-east gradient (Fig. 1).

\section{Laboratory and field data collection}

Considering the environmental units defined by Kandus \& Adámoli (1993), seven levee sampling sites distributed along the region were selected for this study (Fig. 1). At each site, random and stratified censuses were performed, in which ninety-seven $10 \times 10 \mathrm{~m}$ plots were analysed (21 on unit A, 41 on unit B and 35 on unit C); strati were defined regarding the type of neo-ecosystem present. A modified Braun Blanquet (1979) scale (Mueller-Dombois $\delta$ Ellenberg 1974) was used to estimate the cover of each species. Taxonomy and origin of species was according to Cabrera (1963-1968), Burkart (1957, 1969, 1974, 1987) and Cabrera \& Dawson (1944); the types of lifeforms used were based on Barkman (1988).

The degree of abandonment and productive modality were used to define the different types of neo-ecosystems of levees, based on information from the local settlers and managers.

Neo-ecosystem with current anthropization (An): Afforestations (Salix spp. or Populus spp.) with at least an annual removal of the understorey.

Short-term abandonment neo-ecosystem (Sh): 2-7-year-old afforestations. Removal of the understorey only in the first year; from that time on, vegetation starts to regenerate.

Mid-term abandonment neo-ecosystem (M): 8-14-year-old afforestations. Removal of the understorey only in the first year, with the presence of tree species saplings and seedlings in the understorey.
Long-term abandonment neo-ecosystems (Lo): Afforestations that have not been commercialized or subjected to removal of the understory for over 14 years. Remains of the afforestation cover can be found or, if deterioration took place, a new secondary replacement forest.

In all neo-ecosystems analysed afforestation practice had been carried out by an 'open ditch' technique, which allows water to drain quickly from the surface after a flood. In long-term abandonment neo-ecosystems, the original hydrological conditions have re-emerged due to lack of maintenance.

In 45 of the plots analysed (13 of unit A, 15 of unit B and 17 of unit C), soil samples of $20 \times 20 \times 20 \mathrm{~cm}^{3}$ were taken from the surface, discarding the superficial litter. Samples were processed at the Soil Laboratory (INTA, Castelar) and the following parameters were assessed (Black 1965): $\mathrm{pH}$ by the potentiometric technique in paste, acidity by $\mathrm{KCl}$ solution titration, organic matter content (percentage) by the Walkley-Black method, total $\mathrm{N}$ determined by Kjeldahl's method (percentage), percentage of sand, silt and clay fractions by the hydrometric method and electrical conductivity in the saturated paste extract $(\mathrm{mS} / \mathrm{cm})$.

\section{Numerical analysis}

To identify plot groups and detect their main distribution gradients in the region, the classification technique and direct and indirect ordination techniques were applied. The average abundance-cover value of each class interval for each species was estimated with the following percentage: $r=0.01 ;+=0.5 ; 1=3 ; 2=7.5 ; 3=17.5 ; 4=29 ; 5=41.5$; $6=62.5$ and $7=87.5$.

Classification was performed using the TWINSPAN (two-way indicator species analysis, Hill 1979; Gauch 8 Whittaker 1981) program. Cut-off levels to define pseudospecies were $3 ; 7.5 ; 17.5 ; 29 ; 41.5 ; 62.5$ and 87.5 . Only the species with regional constancy values higher than $3 \%$ were considered for the classification analysis. Groups resulting from the classification were characterized by the constancy and relative abundance-cover of species, according to Mueller-Dombois \& Ellenberg (1974). The constancy of each species was calculated as the number of plots on which the species was present relative to the total number of plots for each classification group; abundancecover of species in each classification group was estimated considering only the plots where the respective species was found.

A DCA (detrended correspondence analysis; Hill $\delta$ Gauch 1980) indirect ordination was used to detect species' and plots' order patterns.

To establish the order of plots regarding species composition and edaphic variables, a CCA (canonic 
correspondence analysis; ter Brak 1990) direct ordination was applied.

For both ordinations, the original data were transformed applying square root; rare species were underestimated and a CANOCO program, version 3.12 (ter Braak 1990) was used.

Plot 71 acted as an outlier for all the aforementioned analyses and was therefore left out.

Using the Monte Carlo permutations test (ter Braak 1986), the existence of a correlation with the environmental variables was tested.

Soil samples of the different study area units were compared using a one-way analysis of variance (ANOVA), percentage data will transformed applying arcsin squareroot transform (Zar 1984) and the logarithmic transformation was used on $\mathrm{pH}$ values. Normality and variance homogeneity were tested according to Lilliefords and Bartlett, respectively (Zar 1984); these assumptions were only met for $\mathrm{C} / \mathrm{N}$, clay percentage, conductivity and acidity. The Kruskal-Wallis test was performed when at least one of the assumptions was not met. Scheffé's comparisons were used to analyse the significant differences of the ANOVA; Dunn's (1964) comparisons for unbalanced samples were used for Kruskal-Wallis (Zar 1984).

\section{Results}

Table 1 shows the 65 species with regional constancy values higher than $3 \%$, when all plots were considered.

\section{Classification analysis}

As a result of the classification analysis, plots were divided into two main groups: I and II, which were in turn subdivided into eight subgroups corresponding to neoecosystems with a similar abundance and/or constancy of species (Table 1).

\section{Group I}

This large group contains nearly all the plots from unit A. It includes plots with medium to high constancy values and a low abundance of Panicum grumosum (carrizo), Iris pseudacorus (paleyellow iris), Mimosa pigra (carpinchera) and Cephalanthus glabratus (sarandí).

Considering the relative dominance of the abovementioned species and the abundance and/or constancies of the remaining species, four subgroups were formed (Table 1).

Subgroup I. 1: Includes the majority of plots from unit A and is constituted by all three neo-ecosystem types considered. A number of species showed high constancy in all neo-ecosystems regardless of their abandonment status; they include $P$. grumosum, Carex riparia (latifoliated herbaceous species), Aspilia silphioides (native creeper), Mikania micrantha and three native tree species: Nectandra falcifolia (laurel), C. glabratus and M. pigra. Alien species present in this group showed low constancy and relative abundance values.

Subgroup I. 2: Plots in this group belonged to mediumterm abandonment neo-ecosystems of unit B. I. pseudacorus and P. grumosum had a high constancy but medium to low relative abundance. The remaining species showed low constancy and relative abundance, except for one alien species, Rubus spp. (blackberry), present in nearly half the plots with medium cover values.

Subgroup I. 3: Four plots with medium-term abandonment neo-ecosystems of unit were included in this group. A. Regeneration was observed for C. glabratus, a short native tree, and three native herbaceous species, P. grumosum, Poligonum sp. and Hydrocotyle bonariensis, found in all plots, even though they showed a low relative abundance. It is worth mentioning the presence of Amorpha fructicosa (false indigo), a tree native to North America, in half the plots, although with low abundance.

Subgroup I. 4: Consists of two short-term abandonment neo-ecosystems belonging to unit B in which the cover of most plant species was low. Two alien species were found: A. fructicosa and I. pseudacorus.

\section{Group II}

Most of the plots of neo-ecosystems belonging to units $\mathrm{B}$ and $\mathrm{C}$ were grouped here. Plots were characterized by having high constancy and abundance of two exotic species, Lonicera japonica (Japanese honeysuckle) and Ligustrum sinense (Chinese privet), and medium constancy and medium to high abundance of a number of species, including four alien species: Rubus spp., Ligustrum lucidum (glossy privet), Fraxinus pennsylvanica (green ash) and Morus sp. (mulberry); two native trees: Rapanea spp. (canelón) and Blepharocalyx tweediei (anacahuita); a native shrub, Cestrum parqui (duraznillo negro); and a native graminiform species, $C$. riparia.

The aforementioned species dominance, as well as the remaining species found, helped to divide this group into four subgroups, which could be characterized in terms of the type of neo-ecosystem rather than the regional unit they belonged to (Table 1).

Subgroup II. 5: This first subgroup constitutes an exception to the previous statement, in that it contains plots of short-term abandonment neo-ecosystems in unit A. Its inclusion in this group is explained by the presence of the same dominant species as the rest of the group, 


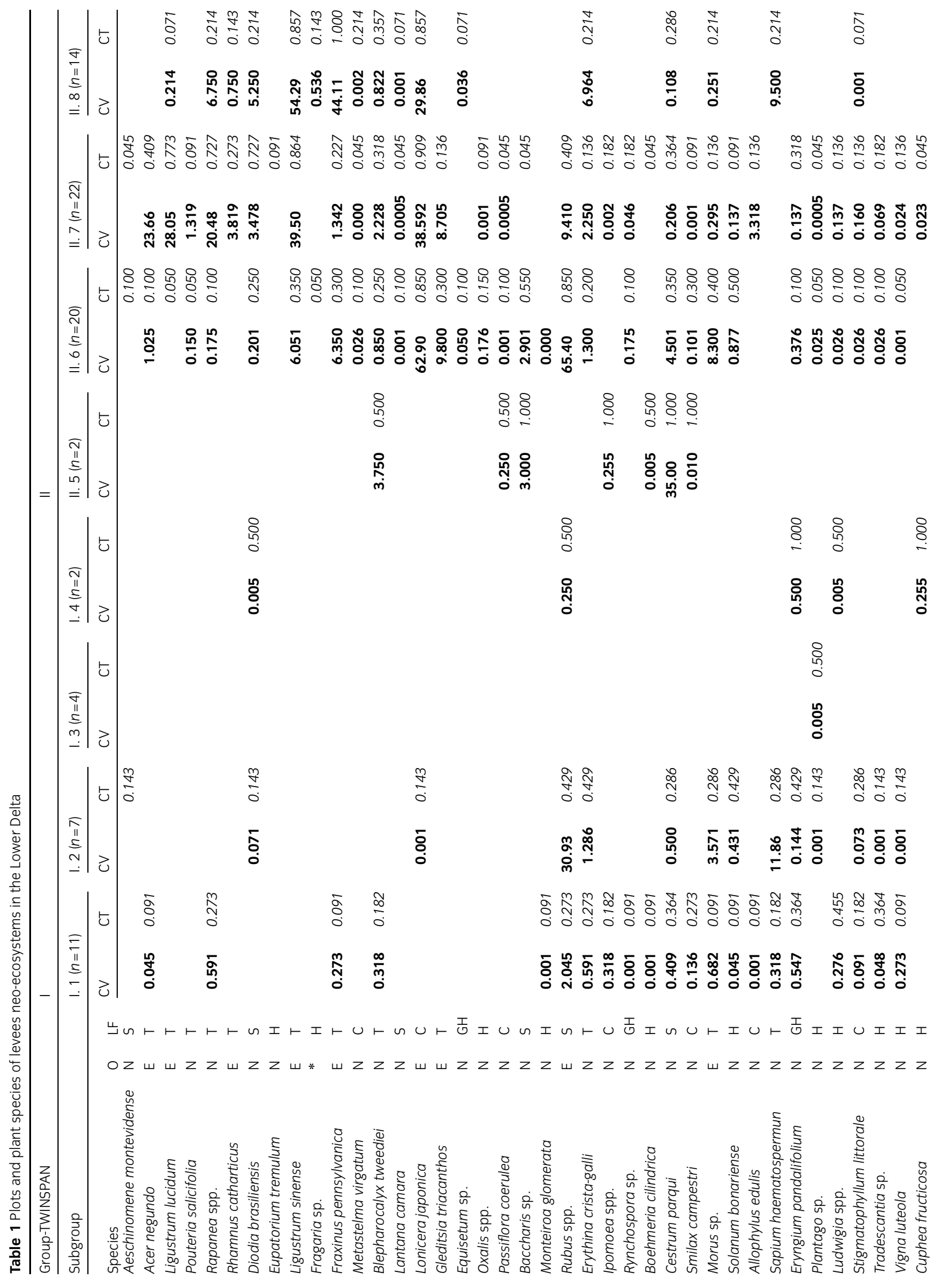


<smiles>[CH]1CCCCC1</smiles>

ฌั<smiles>[C+]1[C-]CC1</smiles><smiles>[C-]1C=[C-]C1</smiles><smiles>[C-][O]</smiles>

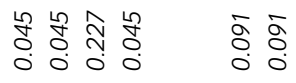

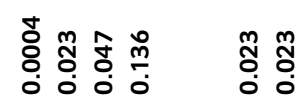

용 $\frac{0}{2}$

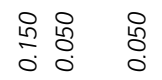

․

占

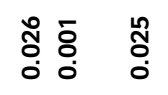

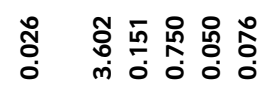

8
0
0
0

$\begin{array}{ll}8 & 8 \\ 0 & 8 \\ 0 & 0 \\ 0 & 0\end{array}$

ณัญ

$\begin{array}{lll}8 & 8 & 8 \\ 8 & 0 \\ -1 & 0 \\ -1 & 0\end{array}$

$\stackrel{8}{\circ}$

$\begin{array}{ll}8 & 8 \\ 0 & 8 \\ 0 & -1 \\ -1\end{array}$

సิ

$\stackrel{m}{\frac{\infty}{0}} \stackrel{\bar{m}}{\stackrel{-}{-}}$

员坥

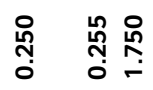

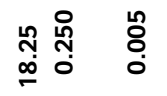

ষ্ণ

8
8
-0
-0

8
0
0
0
0

8
0
0
0

옹 웅

员

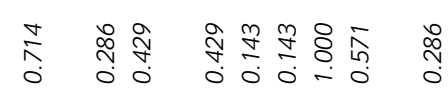

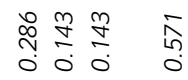

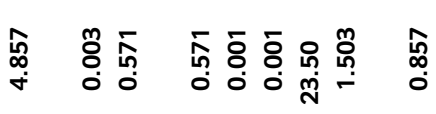

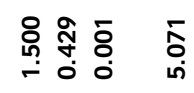

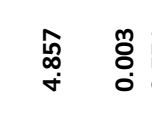

(1)

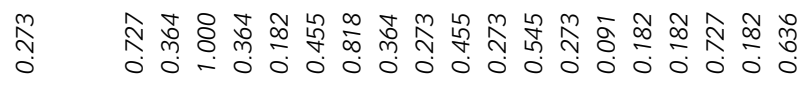

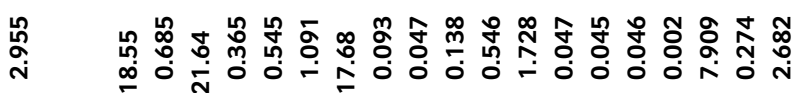

\section{茓 菅}

กั่

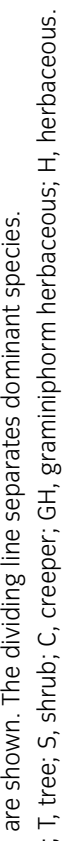

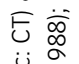

离

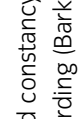

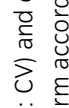

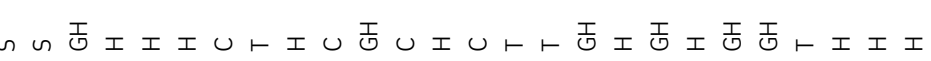

wzzzzzzzzzzzzzzwzzzzzz

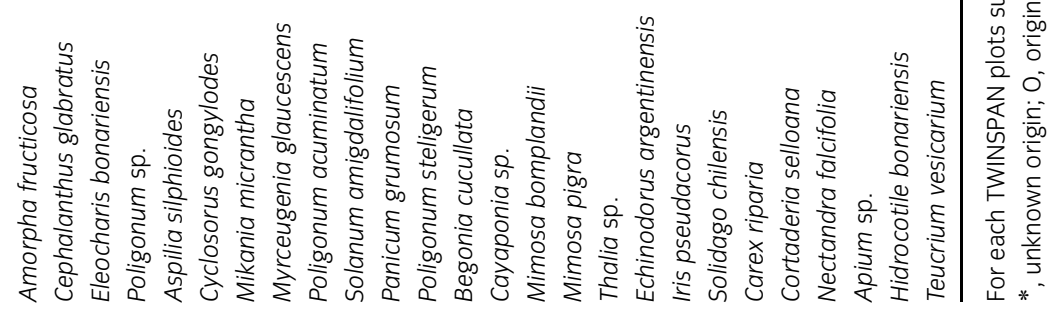


particularly two native trees, B. tweediei and N. falcifolia, and a native shrub, C. parqui.

Subgroup II. 6: Plots in this group consisted of shortterm abandonment neo-ecosystems from both units $\mathrm{B}$ and $\mathrm{C}$, with similar dominant species having the largest covers. Two exotic species dominated: a viner, L. japonica, and a shrub, Rubus spp. To a lesser extent, four alien tree species followed: L. sinense, Gleditsia triacanthos (honeylocust), Morus sp. and F. pennsylvanica.

Subgroup II. 7: Long-term abandonment neo-ecosystems of units B and C formed this group, showing a high constancy and abundance of alien species. Besides the two species characterizing group II ( $L$. japonica and L. sinense), two other exotic species had high development in this subgroup: L. lucidum and Acer negundo (boxelder). Three native species also stood out: two trees, Rapanea spp. and B. tweediei, and a shrub, Diodia brasiliensis.

Subgroup II. 8: Regardless of the type of neo-ecosystem, the plots of this group belonged to unit B. Two exotic tree species dominated: L. sinense and F. pennsylvanica.

\section{Indirect ordination}

Figure 2 shows the distribution of plots in the space defined by the first two axes of the DCA. The variance explained by these axes was $29.2 \%$ ( $11 \%$ by the first and
$18.2 \%$ by the second). Classification subgroups were distributed along these two axes.

The order of plots on the first axis is associated with the environmental unit. All the plots from unit A of group I (subgroups I. 1, I. 3 and I. 4) were located in the positive portion of the first axis, and share the dominance of P. grumosum, with other species varying according to each subgroup. The negative portion holds most of the plots from units B and C (Group II, subgroups II. 6, II. 7 and II. $8)$, the most important species being a group of alien species (L. japonica, Rubus spp., L. sinense, L. lucidum, A. negundo, G. triacanthos and F. pennsylvanica), two native tree species (Rapanea spp. and B. tweediei) and two native shrub species (D. brasiliensis and C. parqui).

The second axis only allows distinction between shortand long-term abandonment neo-ecosystems for units B and $\mathrm{C}$. On the negative side, the plots belonging to subgroup II. 6 (short-term abandonment) were ordered and on the positive side, the ones from subgroup II. 7 (long-term abandonment). The species associated with the first subgroup were mainly L. japonica, Rubus spp. and C. parqui; tree species had a very low association with this subgroup, either native or alien.

The main species in the latter subgroup were three tall alien tree species (L. lucidum, A. negundo and F. pennsylvanica) that formed the canopy of the secondary forest, and a medium-height alien tree species (L. sinense), which

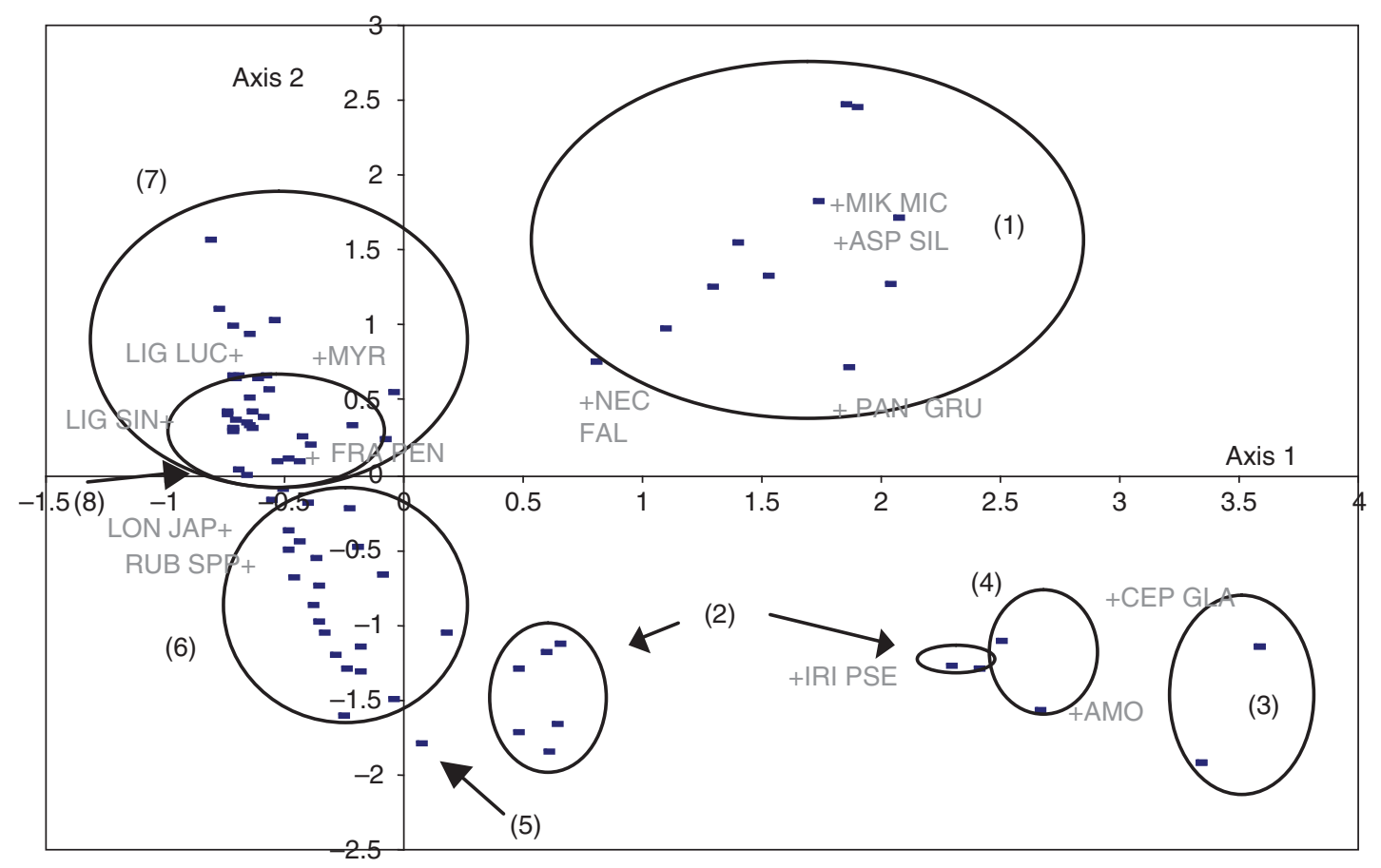

Fig. 2. Plot and main species distribution along the first two axes of the ordination (DCA). The eight groups resulting from classification are shown: 1 , I. 1; 2 , I. $2 ; 3$, I. 3; 4, I. 4; 5, II. 5; 6, II. 6; 7, II. 7 \& 8, II. 8 (TWINSPAN). Genus and species names are shortened by their first three letters. See Table 1. 
formed the middle stratus ( $3-5 \mathrm{~m})$; two native tree species (Rapanea spp. and B. tweediei) were also present as accompanying species in this type of neo-ecosystems.

\section{Edaphic variables}

In Table 2, the main edaphic variables from neo-ecosystems of units A, B and C are shown. Overall, soils analysed had high silt and clay contents and acidic $\mathrm{pH}$ values.

Clay and organic matter contents were significantly different among the environmental units (clay: $F=3.73$; $P=0.032$; organic matter: $H=7.90 ; P=0.019)$, with a higher content in soils of unit B than that of unit C (clay: $P=0.03$; organic matter: $Q=2.69$; $P<0.05)$. For $\mathrm{pH}$ values, a statistical difference between units was also found $(H=9.24$, $P=0.009)$, being slightly lower in unit A than in unit C $(Q=2.88,0.01<P<0.02)$.

Soil texture values (clay, silt and sand) are similar to those reported by Kandus (1997) for low floodable grounds of this area, the ones in this work being slightly lower for clay and slightly higher for silt. This similarity could be due to the fact that in both studies the first $20 \mathrm{~cm}$ of soil were analysed, in which the interaction with the environment is most relevant, the process of active sedimentation after each flood event occurs, and in which the inherited material is less relevant. Future studies would require all soil horizons to be studied.

\section{Vegetation and edaphic parameters}

The distribution of plots, main soil variables and species in the space defined by the two first axes of the CCA are shown in Fig. 3. The total variance for this analysis was 5.182 , with $65.2 \%$ of it explained by the axes. The fraction explained by the chosen edaphic variables represents $17.37 \%$ of the total variance. Plots distributions differ significantly from a random distribution for the first axis (Monte Carlo's test: autovalue $=0.34$, $F=2.66, P<0.03)$; the same is true when the total restricted variance is considered (trace $=0.90, F=1.59$, $P<0.01)$.

The negative end of axis 1 grouped the majority of plots from unit A, including all types of neo-ecosystem. Plots from units $\mathrm{B}$ and $\mathrm{C}$ were located in the positive side over the central zone. Two edaphic variables were found to be strongly associated with this distribution of plots along the first axis of the CCA: $\mathrm{pH}$ and silt content $(r=0.924$ and 0.43 , respectively).

Organic matter content and conductivity were correlated to the second axis ( $r=0.62$ and 0.566 , respectively) although no clear distribution of plots was observed in relation to them.

\section{Discussion}

The present work is the first to incorporate the levee neoecosystems into the regionalization model for the Lower Delta of the Paraná River proposed by Kandus (1997). These neo-ecosystems are plant communities of recent origin that are closely related to the local productive activities. With the addition of communities with a high regional development, the model acquires a broader range. In our findings, neo-ecosystems belonging to the environmental unit A showed a clear distinction from those of units $\mathrm{B}$ and $\mathrm{C}$, which showed a combined expression of similar vegetation responses.

Neo-ecosystems of unit A are more similar to each other to the corresponding neo-ecosystem, in terms of degree of abandonment, of the other units (e.g. vegetation of long-term abandonment neo-ecosystems of unit A

Table 2 Soil variables in the neo-ecosystems studied

\begin{tabular}{|c|c|c|c|c|c|c|c|c|c|c|}
\hline Unit & $\begin{array}{l}\text { Number of } \\
\text { stands }\end{array}$ & $\begin{array}{l}\text { Organic } \\
\text { matter (\%) }\end{array}$ & $\begin{array}{l}\text { Nitrogen } \\
(\%)\end{array}$ & $\mathrm{C} / \mathrm{N}$ & Clay & Silt & Sand & $\mathrm{pH}$ & Acidity & $\begin{array}{l}\text { Conductivity } \\
(\mathrm{mS} / \mathrm{cm})\end{array}$ \\
\hline \multicolumn{11}{|l|}{$\bar{A}$} \\
\hline Mean & 13 & 4.37 & 0.23 & $11.18 \mathrm{a}$ & $25.21 \mathrm{ab}$ & 55.13 & 19.58 & 5.51 & $9.1 \mathrm{a}$ & $0.31 \mathrm{a}$ \\
\hline Median & & $4.05 a b$ & $0.23 a$ & 10.19 & 24.3 & $58.5 \mathrm{a}$ & $12.6 \mathrm{a}$ & $5.5 \mathrm{a}$ & 8.8 & 0.3 \\
\hline Standard deviation & & 2.17 & 0.12 & 1.75 & 7.36 & 11.23 & 16.95 & 0.3 & 2.73 & 0.08 \\
\hline \multicolumn{11}{|l|}{$B$} \\
\hline Mean & 17 & 6.16 & 0.32 & $11.7 \mathrm{a}$ & $27.34 \mathrm{a}$ & 57.54 & 15.33 & 5.74 & $10.5 \mathrm{a}$ & $0.36 a$ \\
\hline Median & & $6.27 \mathrm{a}$ & $0.34 \mathrm{a}$ & 11.3 & 26.3 & $58 a$ & $15.3 \mathrm{a}$ & $5.8 \mathrm{ab}$ & 10.7 & 0.33 \\
\hline Standard deviation & & 2.49 & 0.13 & 2.11 & 5.78 & 4.4 & 6.11 & 0.17 & 2.46 & 0.08 \\
\hline \multicolumn{11}{|l|}{ C } \\
\hline Mean & 15 & 3.706 & 0.29 & $11.99 a$ & $21.5 b$ & 57.85 & 19.58 & 5.8 & $8.18 \mathrm{a}$ & $0.33 a$ \\
\hline Median & & $3.76 \mathrm{~b}$ & $0.22 \mathrm{a}$ & 12.3 & 22.4 & $63.3 \mathrm{a}$ & $11.7 \mathrm{a}$ & $5.8 \mathrm{~b}$ & 7.6 & 0.32 \\
\hline Standard deviation & & 2.73 & 0.29 & 1.83 & 5.08 & 13.39 & 16.95 & 0.21 & 3.12 & 0.08 \\
\hline
\end{tabular}

Same letters in each column show no differences found using Scheffé multiple comparison test (ANOVA, F) and Dunn's multiple comparison test for Kruskall-Wallis (H). Significant differences, $P<0.05$. 
Fig. 3. Canonic ordination of plots from the different environmental units of the Lower Delta of the Parana River. Genus and species names are shortened by their first three letters. See Table 1. 1, Ligustrum sinense; 2, Lonicera japonica; 3, Gleditsia triacanthos; 4, Fraxinus pennsylvanica; 5, Rapanea spp. See Table 1. Sh, short-term abandonment neo-ecosystem; $M$, mid-term abandonment neo-ecosystem; Lo, long-term abandonment neo-ecosystem.

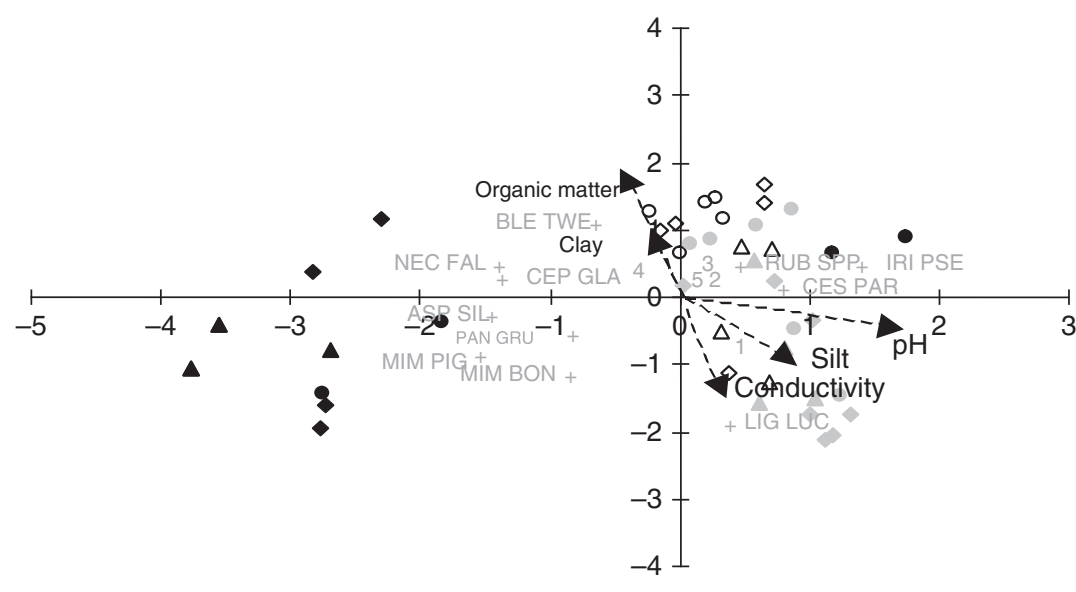

\begin{tabular}{|c|c|c|}
\hline - Unit A - (Sh) & $\Delta$ Unit A - (M) & - Unit A - (Lo) \\
\hline o Unit B - (Sh) & $\Delta$ Unit $\mathrm{B}-(\mathrm{M})$ & $\diamond$ Unit B - (Lo) \\
\hline - Unit C - (Sh) & $\triangle$ Unit $\mathrm{C}-(\mathrm{M})$ & Unit $C-v(L o)$ \\
\hline
\end{tabular}

holds a stronger relationship with that of short- and medium-term abandonment neo-ecosystems of the same unit than with long-term neo-ecosystems of units B and C). This could be because all types of levees neo-ecosystems of unit A showed a high development of P. grumosum (carrizo). Despite functioning as different systems in terms of the local hydrological regime and the natural plant communities' response (Kandus 1997), units B and $\mathrm{C}$ had a similar composition of neo-ecosystems of levees. These are characterized by a high development of a group of alien species that leads to a convergence in the structure and composition of vegetation. In short-term abandonment neo-ecosystems, an Asian creeper, L. japonica (Japanese honeysuckle), and a European shrub, Rubus spp. (blackberry), dominated, with a conspicuous absence of tree species. On the other hand, medium- and longterm abandonment neo-ecosystems were dominated by a group of alien tree species, particularly L. sinense (Chinese privet) and $F$. pennsylvanica (green ash) and regeneration of native tree species could also be observed, such as Rapanea spp. (canelón) and B. tweediei (anacahuita), especially in long-term abandonment neo-ecosystems.

The difference found in levee neo-ecosystems between the environmental units could be related to the greater fluvial influence received by unit A and the greater tidal influence on units B and C. Classification and ordination analyses reflected the same relationship. Therefore, neoecosystems of riverside wetlands influenced by the hydrological regime of the Paraná River and neo-ecosystems of wetlands subjected to the tides of the De la Plata River can be differentiated.
According to Malvárez (1997), in fluvial systems, river overflows represent an energy benefit with water and nutrient contribution. Beyond a certain threshold, disturbances start to occur that alter the substrate (organic matter, nutrient or sediment removal, erosion and sedimentation) and can cause loss of biomass in the vegetation communities. This is exacerbated during extraordinary floods, like the ones that took place during 1982-1983 due to 'El Niño'. Species found in unit A's neo-ecosystems would be related to the fluvial conditions and to the effects of the extraordinary floods mentioned previously. Both factors would cause homogenization of vegetation by the dominance of P. grumosum and its accompanying native species, regardless of the type of neo-ecosystem. These species' adaptations allow them to tolerate the typical flood-drought conditions of a seasonal fluvial regime, recovering after a disturbance (Morello 1949; Burkart 1957; Neiff 1979, 1986; Kandus 1997). They reach their highest development upstream, in the middle and upper portions of the delta, and could be considered as part of an ingression process into the highest fluvial influence sector of the Lower Delta (Malvárez 1997).

In contrast to the previous, units $B$ and $C$ have a strong tidal influence from the De la Plata River, and are subjected to high-amplitude water-level oscillations (Kandus 1997). The tidal regime of the De la Plata River affects the whole Lower Delta, which is classified according to Mitsch \& Gosselink (2000) as a broad 'wetland subjected to freshwater tidal regime'. Therefore, these two units would receive supplementary water contributions that could compensate the seasonal drought periods of soils, 
and provide a greater availability of nutrients (Malvárez 1997). This allows the settlement of a greater number of species, the development of a larger biovolume and an increase in the structural complexity (Kalesnik 2001). The latter effect validates the large number of tree, shrub, herbaceous and creeper species that form the vegetation of the different types of neo-ecosystem, giving rise to secondary pluristratified forests in long-term abandonment type. Under these environmental conditions, a group of exotic species develop that can also be found in neo-ecosystems of the De la Plata River's riverside due to their regional scope invasive process (Dascanio et al. 1994; Cagnoni et al. 1996; Matteucci et al. 1999; Kalesnik \& Malvárez 2003; Kalesnik \& Kandel 2004; Kalesnik et al. 2005).

Finally, the characteristics of the hydrological regimes of the Lower Delta would only partially affect soils of levees' neo-ecosystems in the islands. A relationship between the edaphic parameters and the environmental units would exist, but independent of the type of neo-ecosystem. The lower $\mathrm{pH}$ values observed in soils of the environmental unit A could be related to the greater fluvial influence that would cause a longer persistence of the saturating conditions found in high flow season (Kandus 1997), later drying in the drought season, causing a partial mineralization of soils. Another interesting result is the larger organic matter content found in soils of unit B when compared with unit C. Similar findings were obtained by Kandus (1997), who established unit B to be a transitional state between unit A upstream and unit C downstream. Therefore, unit B would have more evolved soils than unit $\mathrm{C}$, and with a lesser disturbance frequency than in unit $\mathrm{A}$. In addition, the vertical water oscillations in unit B are of a lesser amplitude than in unit C, and the high flows of the Paraná River have a deaden influence. The biogenic accumulation processes would thus be favoured in this unit, which could partially explain the higher clay and silt percentages found here.

\section{Conclusion}

In conclusion, to fully understand the spatial pattern of vegetation in levees' neo-ecosystems in islands of the Lower Delta, it is necessary to take into account not only the abiotic factors but also the alien species invasion process that has been taking place in the region for over 50 years.

\section{Acknowledgements}

This work is dedicated to the memory of Dr. Ana Inés Malvárez (1948-2005). It was possible thanks to the UBACYT Ex. 273 research grant and the award granted to Dr. Fabio Kalesnik by the MAB-UNESCO young researchers program, Paris, France, 2004.
We thank the local residents (isleños), Municipio de San Fernando and Gestión de la Reserva de Biosfera Delta del Paraná's committee for the logistical support. We specially thank the review and suggestions by Prof. Mark Brinson and an anonymous reviewer.

To submit a comment on this article please go to http:// mc.manuscriptcentral.com/wej. For further information please see the Author Guidelines at www.wileyonlinelibrary.com

\section{References}

Barkman, J. (1988) New Systems of Plants Growth Forms and Phenological Plant Types. In Werger, M.A.J., van der Aart, P.J.M., During, H.J. and Verhoeven, J.T.A. (eds). Plant Form and Vegetation Structure, pp. 9-44. SPB Academic Publishing, The Hague.

Black, C.A. (1965) Methods of Soil Analysis. Agronomy. Monograph No. 9. Part. 1. ASA, Madison, WI, USA.

Bonetto, A. (1986) The Paraná River System. In Davies, B.R. and Walker, K.F. (eds). The Ecology of River Systems, pp. 541-554. Dr. Junk Publ., Dordrecht.

Bonfils, C. (1962) Los suelos del Delta del Río Paraná. Factores generadores, clasificación y uso. Revista Investigación Agrícola, Vol. 16(3). INTA, Buenos Aires, Argentina, pp. 257-270.

Braun Blanquet, J. (1979) Fitosociología: Bases para el estudio de las comunidades vegetales. Blume, España, 820 pp.

Burkart, A. (1957) Ojeada sinóptica sobre la vegetación del Delta del Río Paraná. Darwiniana, 11, 457-561.

Burkart, A. (1969) Flora ilustrada de Entre Ríos (ARGENTINA). Parte II. Col. Cient. INTA, Buenos Aires.

Burkart, A. (1974) Flora ilustrada de Entre Ríos. Col. Cient. INTA, Buenos Aires, Argentina.

Burkart, A. (1987) Flora ilustrada de Entre Ríos (ARGENTINA). Parte III. Col. Cient. Tomos VI, III. INTA, Buenos Aires.

Cabrera, A.L. (1963-1968) Flora de la Provincia de Buenos Aires. INTA, Colección Científica, Vol. 4, Part 1, 623 pp., Part 2, 624 pp., Part 3, 672 pp., Part 4, 418 pp., Part 5, 606 pp., Part 6, $554 \mathrm{pp}$.

Cabrera, A.L. and Dawson, G. (1944) La Selva Marginal de Punta Lara, en la Rivera Argentina del Río de La Plata. Revista del Museo de La Plata (new series), Sección Botánica, Vol. V, pp. 267-382. Universidad de La Plata, Buenos Aires.

Cagnoni, M., Faggi, A. and Ribichich, A. (1996) La vegetación de la Reserva "El Destino". Parodiana, 9 (1-2), 25-44.

Dascanio, L.M., Barrera, M. and Frangi, J. (1994) Biomass Structure and Dry Matter Dynamics of Subtropical Alluvial and Exotic Ligustrum Forest at the Río de la Plata, Argentina. Vegetatio, 115, 61-76.

Dirección Nacional de Construcciones Portuarias y Vías Navegables Anuario Hidrográfico (1976-1980) (DNCP). (1983) Secretaría de Intereses Marítimos. Ministerio de Economía, Buenos Aires, Argentina.

Dunn, O.J. (1964) Multiple Contrats Using Rank Sums. Technometrics, 6, 241-252.

Gauch, H.G. and Whittaker, R.H. (1981) Hierarchical Classification of Community Data. J. Ecol. (69), 537-557. 
Godagnone, R., Bertola, H. and Ancarola, M. (2002) Mapa de Suelos de la República Argentina. Scale 1:2.500.000. Instituto de Suelos INTA y Instituto Geográfico Militar, Buenos Aires.

Gosselink, J.G. and Turner, R.E. (1978) The Role of Hidrology in Freshwater Wetland Ecosystems. In Good, R., Whigham, D. and Simpson, R.L. (eds). Freshwater Wetlands, pp. 63-78. Academic Press, New York.

Hill, M.O. (1979) TWINSPAN. A FORTRAN program for arranging multivariate data in an ordered two-way table by classification of the individuals and attributes. Unpublished Report, Cornell University, Ithaca, NY.

Hill, M.O. and Gauch, H.G. (1980) Detrended Correspondence Analysis: An Improved Ordination Technique. Vegetatio, 42, 47-58.

Kalesnik, F. (2001) Relación entre las comunidades vegetales de los neoecosistemas de albardon y la heterogeneidad ambiental del bajo delta del Rio Paraná. Tendencias sucesionales y proyección sobre la composición futura. Doctoral Thesis, Universidad de Buenos Aires, Buenos Aires, 230 pp.

Kalesnik, F. and Kandel, C. (2004) Reserva de Biosfera Delta del Paraná. Formación en educación para el ambiente y el desarrollo. Unesco - Municipalidad de San Fernando, Argentina, p. 255.

Kalesnik, F. and Malvárez, A.I. (2003) Las especies invasoras exóticas en los sistemas de Humedales. El caso del Delta Inferior del Río Paraná, Vol. 12. INSUGEO, Miscelánea, Tucumán, pp. 5-12, ISSN 1514-4836.

Kalesnik, F., Cagnoni, M., Bertolini, P., Quintana, R., Madanes, N. and Malvárez, A.I. (2005) La vegetación del Refugio Educativo de la ribera norte, provincia de Buenos Aires, Argentina. Invasión de especies exóticas, Vol. 14. INSUGEO, Miscelánea, Tucumán, Argentina, pp. 97-107, ISSN: 1514-4836.

Kandus, P. (1997) Análisis de patrones de vegetación a escala regional en el Bajo Delta Bonaerense del Río Paraná

(Argentina). Doctoral Thesis, Universidad de Buenos Aires, Buenos Aires.

Kandus, P. and Adámoli, J.M. (1993) Freshwater Marsh Vegetation Response to Flooding Patterns in the Lower Delta of the Paraná River. Wetlands Ecol. Manage., II (4), 213-222.

Latinoconsult, S.A. (1972) Estudio integral para el desarrollo del Delta del Paraná bonaerense, Vol. III. Ministerio de Economía. Direc. de proyecto, Buenos Aires, Argentina.

Lugo, A.E., Brinson, M. and Brown, S. (1990) Synthesis and Search for Paradigms in Wetland Ecology. In Lugo, A.E., Brinson, M. and Brown, S. (eds). Forested Wetlands. Ecosystems of the World, Vol. 15 , pp. 447-460. Elsevier, Amsterdam.

Malvárez, A.I. (1997) Las comunidades vegetales del Delta del Río Paraná. Su relación con factores ambientales y patrones de paisaje. Doctoral Thesis, Universidad de Buenos Aires, Buenos Aires.

Matteucci, S., Morello, J., Rodriguez, A., Buzai, G. and Baxendale, C. (1999) El crecimiento de la metrópoli y los cambios de biodiversidad: el caso de Buenos Aires. En: Biodiversidady uso de la tierra. Conceptos y ejemplos de Latinoamérica, 580 pp. EUDEBA, Argentina.
Menalled, F. and Adámoli, J. (1995) A Quantitative Phytogeographic Analysis of Richness in Forest Communities of the Paraná River Delta, Argentina. Vegetatio, 120, 81-90.

Mitsch, W. and Gosselink, J. (2000) Wetlands. Van Nostrand, New York, 722 pp.

Morello, J., Buzai, G., Baxendale, C., Matteucci, S., Rodriguez, A., Godagnone, R. and Casas, R. (2000) Urbanización y consumo de tierra fértil. Ciencia Hoy, 10, 50-61.

Morello, J.H. (1949) Las comunidades vegetales de las islas cercanas al puerto de Rosario. Museo de La Plata Thesis, No. 133, La Plata.

Mueller-Dombois, D. and Ellenberg, H. (1974) Aims and Methods of Vegetation Ecology. J. Wiley, New York, p. 547.

Mujica, F. (1979) Estudio ecológico y socioeconómico del Delta Entrerriano. Parte I. Ecología. Instituto Nacional de Tecnología Agropecuaria, Pananá.

Neiff, J.J. (1979) Fluctuaciones de la vegetación acuática en ambientes del valle de inundación del Paraná Medio. Physis, 38, 41-53.

Neiff, J.J. (1986) Aquatic Plants of the Paraná System. In Davies, B.R. and Walker, K.F. (eds). The Ecology of River Systems, pp. 557-571. Dr. Junk Publishers, Dordrecht.

Servicio Meteorol ó gico Nacional. (1980) Estadísticas climatológicas. Serie B No. 6. Fuerza Aérea Argentina, Buenos Aires, Argentina.

Soil Survey Staff. (2003) Keys to Soil Taxonomy USDA (9th edn). Soil Survey Staff, $332 \mathrm{pp}$. United States Department of Agriculture, Natural Resources Conservation Service, WA, USA.

Summerfield, M.A. (1991) Global Geomorphology. An Introduction to the Study of Landforms. Longman Scientific $\theta$ Technical. John Wiley \& Sons, New York.

ter Braak, C.J. (1990) Update Notes: CANOCO Version 3.10. Agricultural Mathematics Group, Wageningen.

ter Braak, C.J.F. (1986) Canonical Correspondence Analysis: A New Eigenvector Technique for Multivariate Direct Gradient Analysis. Ecology, 67, 1167-1179.

Vallés (2004) Las especies exóticas invasoras en los bosques secundarios y parches relictuales de Monte Blanco en los albardones del Bajo Delta del Río Paraná. Comparación de sus Banco de Semillas. Director: Fabio Kalesnik. Graduated Thesis, Universidad de Buenos Aires, Buenos Aires, 60 pp.

Vallés, L., Kalesnik, F. and Malvarez, A.I. (2005) Los parches relictuales de Monte Blanco del área núcleo de la Reserva de Biosfera MAB-UNESCO “Delta del Paraná". In Humedales Fluviales de América del Sur. Hacia un manejo sustentable. Fundation Proteger (ed). Julieta, Peteán and Jorge, Cappato (compilators), 560 pp. Santa Fé, Argentina.

Valli, S. (1990) Tendencia de las forestaciones en el Delta del Río Paraná y sus implicancias ecológicas. In Adámoli, J. and Malvárez, A.I. (eds). En Condicionantes ambientales y bases para la formulación de alternativas productivas y ocupacionales en la Región Delta. Technical report UBACyT No. 135, pp. 43-60. University of Buenos Aires, Buenos Aires.

Zar, H.J. (1984) Biostatistical Analysis. Prentice-Hall Inc., Englewood Cliffs, NJ. 